Diabetologia (1994) 37: 15-21

\title{
Effect of nutrients, hormones and serum on survival of rat islet beta cells in culture
}

\author{
Z. Ling, J.C.Hannaert, D. Pipeleers \\ Department of Metabolism and Endocrinology, Vrije Universiteit Brussel, Brussels, Belgium
}

Summary This study quantifies the survival of purified single rat beta cells under different culture conditions. Less than $10 \%$ of the cells survive 9 days of culture in Ham's F10 medium without supplements. Addition of fetal calf serum $(5 \%)$ increases cell survival to $54 \%$ in the absence and to $78 \%$ in the presence of isobutylmethylxanthine $(50 \mu \mathrm{mol} / 1)$. The effect of serum is explained, at least partly, by the presence of albumin and of low molecular weight constituents. In serum-free Ham's F10 with $50 \mu \mathrm{mol} / 1$ isobutylmethylxanthine, $75 \%$ of cells survive after the addition of bovine serum albumin $(1 \%)$ and of ultroser $(0.2 \%)$, a commercial serum substitute. Survival of at least $75 \%$ of cells is also maintained in Ham's F10 with isobutylmethylxanthine plus albumin, and supplemented by metabolizable nutrients or by the peptides glucagon $\left(10^{-8} \mathrm{~mol} / \mathrm{l}\right)$ or growth hormone $(1 \mu \mathrm{g} / \mathrm{ml})$ plus insulin like growth factor-I (50 $\mathrm{ng} / \mathrm{ml}$ ). D-Glucose increases beta-cell survival in a dose- dependent manner up to $10 \mathrm{mmol} / \mathrm{l}$; a beneficial effect is also observed with other metabolizable compounds (leucine and glutamine) but not with non-metabolizable monosaccharides. Glucose-induced survival of islet beta cells can be attributed to its dose-dependent recruitment of cells into metabolic activities; however, a 9-day exposure to excessively high nutrient concentrations ( $>20 \mathrm{mmol} /$ lglucose) is deleterious to the cells. These results define culture media, with or without serum, wherein at least $75 \%$ of single rat islet beta cells can survive for a minimum of 9 days. This will allow for studies on beta-cell toxic conditions and potentially protective agents. The data also serve as basis for developing media with better survival of beta cells in cultured aggregates. [Diabetologia (1994) 37:15-21]

Key words Islets, beta cells, culture, glucose, growth hormone.
The use of pancreatic beta-cell culture varies from studies on long-term regulation of cells to preservation of islet grafts up to the day of transplantation. Various media have been used to maintain islet beta-cell preparations in culture. Previous papers have reported how the medium content in serum, glucose and hormones may influence the function of islets and islet cell lines that are recovered from culture [1-5]. Information is scarce on the extent of cell losses under different culture conditions. These losses may vary with

Received: 28 April 1993

and in revised form: 8 July 1993

Corresponding author: Professor D. Pipeleers, Department of Metabolism and Endocrinology, Vrije Universiteit Brussel, Laarbeeklaan 103, B-1090 Brussels, Belgium the type of medium used as well as with the species, age and functional state of the cells, and with their micro-anatomic organization. In the present paper, we have measured, over a 9-day culture period, the survival of single adult beta cells which were purified from adult rat pancreata [6] and incubated in media of different composition. Under the selected test conditions, the number of plated cells remains stable; living and dead cells are distinguished by vital staining. This model allows direct measurement of beta-cell survival which is not yet possible in intact islets or unpurified islet cell preparations. The aim is to select medium constituents which promote the survival of beta cells in culture. This information can be used to compose defined media in which conditions toxic to the beta cell can be identified and protective agents recognized. It will also serve further studies which aim to de- 


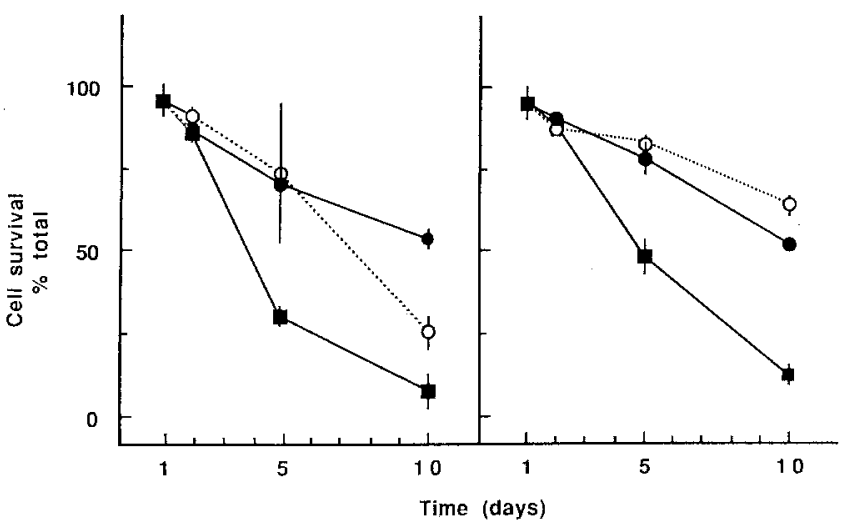

Fig. 1. Survival of single purified beta cells after 1 to 9 days culture in Ham's F10 without (left panel) or with (right panel) $1 \%$ bovine serum albumin. Media without supplements (a) were compared with media containing $5 \%$ fetal calf serum (e) or $0.2 \%$ ultroser $(O)$. Data represent mean \pm SEM of 3 to 5 experiments

velop media for the preservation of beta cells in aggregated form, which is more relevant for transplantation purposes.

\section{Materials and methods}

\section{Preparation of purified islet cells}

Pancreatic islets were isolated from adult male Wistar rats by collagenase digestion and dissociated into single cells in calciumfree medium containing trypsin and DNase [6]. Single beta (more than $95 \%$ pure) and islet endocrine non-beta cells were collected after autofluorescence-activated sorting of the dissociated cells [6].

\section{Culture}

Purified single islet cells were distributed over polylysine-coated microtitre cups $\left(3 \cdot 10^{3}\right.$ cells per cup with $200 \mu \mathrm{I}$ medium) [7]. The cells rapidly fixed on the bottom and remained largely $(>80 \%)$ single over the 9-day culture period, so that dead and living cells could be easily identified following staining of live cells with neutral red [7]. Under these conditions, the number of plated cells remained stable between day 1 and day 10: this was concluded after repeated countings of all cells in a fixed area (more than 400 cells per area). Consequently, the percentage of neutral red positive cells can be used as an index of cell survival throughout culture.

Culture occurred in Ham's F10 (Flow, Irvine, UK) containing $0.075 \mathrm{mg} / \mathrm{ml}$ penicillin and $0.1 \mathrm{mg} / \mathrm{ml}$ streptomycin, and supplemented with one or more of the following test agents: heat-inactivated fetal calf serum (FCS, Flow), Ultroser-G (Gibco, Paisley, Scotland, UK), bovine serum albumin (BSA, fraction V, RIA grade, Sigma, St. Louis, Mo., USA), 3-isobutyl-1-methylxanthine (IBMX, Janssen Chimica, Beerse, Belgium), D-glucose, L-glucose, L-fructose, L-galactose, L-sorbitol, L-leucine, L-glutamine, human recombinant insulin-like growth factors I or II (IGF-I, IGF-II, kindly donated by Fujisawa Pharmaceutical Co. Ltd., Osaka, Japan, to J.L. Van den Brande, University of Utrecht, The Netherlands), mouse epidermal growth factor
(EGF, Sigma), bovine fibroblast growth factor (Gibco), human growth hormone (Nordisk Gentofte, Denmark), porcine glucagon (Novo, Copenhagen, Denmark), porcine insulin (Novo), porcine somatostatin (Beckman, Palo Alto, Calif., USA), triiodothyronine $\left(\mathrm{T}_{3}, \mathrm{Gibco}\right)$, bovine transferrin (Sigma), sodium selenite (Gibco). To eliminate low molecular weight agents from serum, from albumin or from ultroser, these preparations were treated with charcoal $(10 \mathrm{mg} / \mathrm{ml}$ - three times for serum and albumin, four times for ultroser) before addition to the media. The cells were cultured at $37^{\circ} \mathrm{C}$ under $95 \%$ air $/ 5 \% \mathrm{CO}_{2}$ in a $\mathrm{CO}_{2}$-incubator. Media were replaced every other day and assayed for insulin.

\section{Measurement of cell survival, insulin content and release}

Cell survival was determined on freshly isolated (day 1) and cultured islet cells. A neutral red stock solution was added to the culture medium ( $0.01 \%$ final concentration) and the percentage of neutral red positive cells was counted [7]. Insulin release during culture was measured in aliquots of the medium that was removed every other day. The rate of insulin degradation in the medium was less than $5 \%$ which was evaluated by adding porcine insulin (Novo) to the culture media and assessing its recovery after 9 days. Insulin release was expressed as ng per day and per $10^{3}$ cells at the start. Cellular insulin content was measured in the preparations at the start and after 9 days of culture. Cells were extracted in $1 \mathrm{ml} 2 \mathrm{~mol} / \mathrm{l}$ acetic acid with $0.25 \% \mathrm{BSA}$ and dried samples of the extract were processed for the immunoassay [6]; cellular insulin content was calculated per $10^{3}$ cells at the start.

\section{Statistical analysis}

Each condition was tested in a minimum of four independent experiments, i. e. with cells from different rats and islet isolations. Each experiment included a control condition with basal medium. All data are expressed as mean \pm SEM from independent experiments. The statistical significance of differences between the experimental conditions was calculated by unpaired Student's $t$-test or by a one-way analysis of variance (ANOVA).

\section{Results}

\section{Effect of serum on survival of single beta cells during culture}

Immediately after their isolation, more than $90 \%$ of purified islet beta cells stained positively with neutral red. The same percentage of viable cells was found after 1 day of culture in Ham's F10 containing $6 \mathrm{mmol} / 1$ glucose (Fig. 1) while only $60 \%$ positive cells were counted in CMRL-1066 medium (data not shown). Most cells died during the subsequent 4 to 9 days of culture (Fig. 1). Cell survival improved when FCS was added to the culture medium, from a concentration of $1 \%$ (volume/volume $\mathrm{v} / \mathrm{v}$-data not shown) up to a maximal effect at $5 \%(\mathrm{v} / \mathrm{v})$ (Fig. 1). The beneficial action of FCS was reduced by $50 \%$ with absorption on charcoal (data not shown), indicating that it partly results from 
Table 1. Effect of serum, bovine serum albumin (BSA) and isobutylmethylxanthine (IBMX) on the survival of islet beta cells

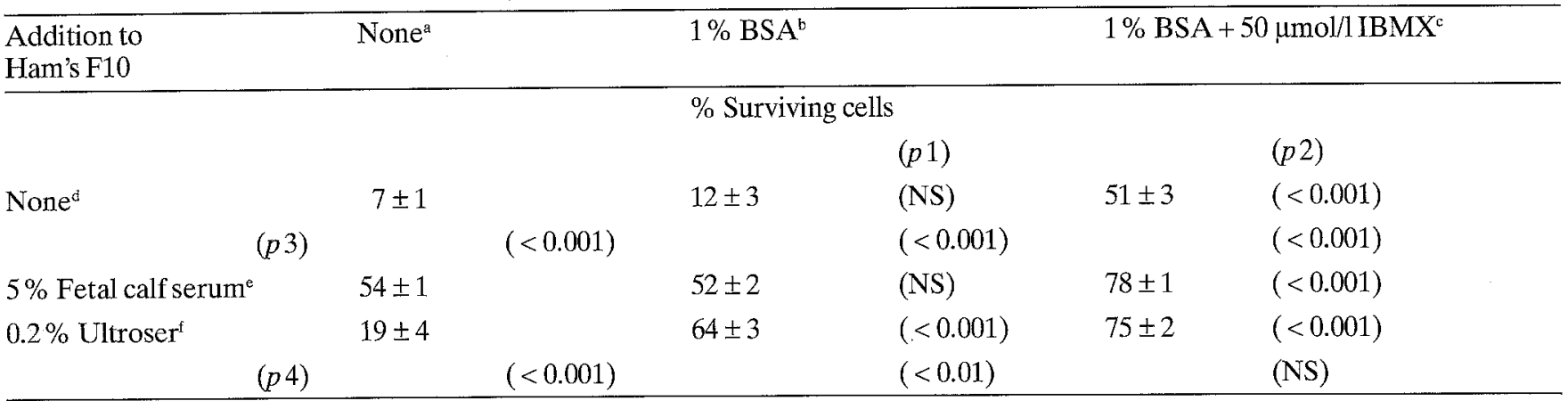

Data represent mean \pm SEM of 4 or 5 experiments. ANOVA is used to calculate statistical significance of differences between a and ${ }^{\mathrm{b}}(p 1)$ or ${ }^{\mathrm{c}}(p 2)$, and between ${ }^{\mathrm{e}}$ and ${ }^{\mathrm{d}}(p 3)$ or ${ }^{\mathrm{f}}(p 4)$

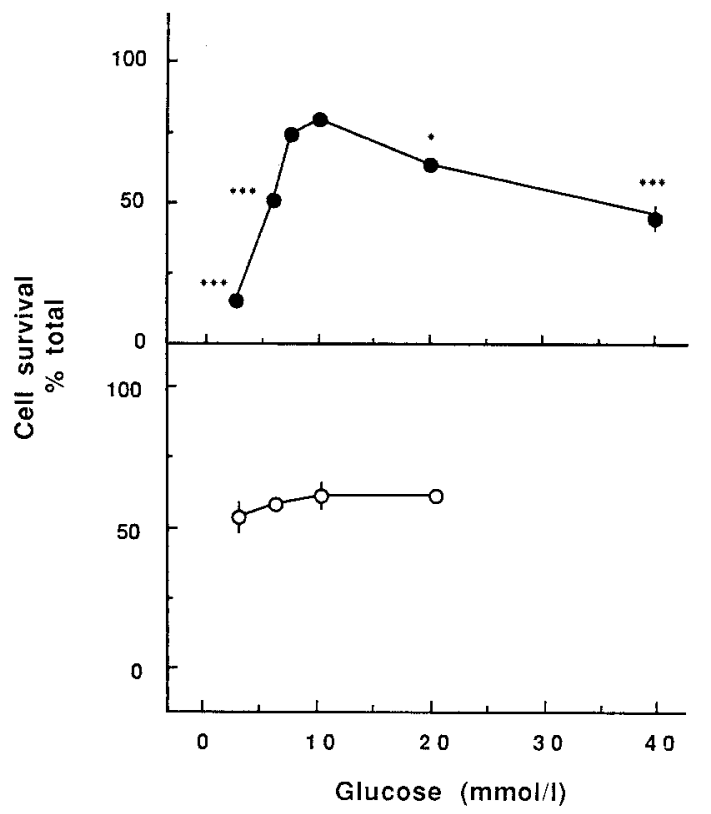

Fig. 2. Survival of single purified beta (upper panel) and islet endocrine non-beta cells (lower panel) after 9 days of culture at different concentrations of glucose. Data represent mean \pm SEM of 4 to 10 experiments. $* p<0.05$, *** $p<0.001$ vs $10 \mathrm{mmol}$ glucose (unpaired Student's $t$-test)

the presence of small molecules. Ultroser $(0.2 \%)$ exerted a protective effect during the first 4 days of culture (Fig. 1). This effect was completely absorbed by charcoal (data not shown), and thus could be attributed to small molecules. Supplementation of the ultroser medium with charcoal-pretreated albumin (BSA, 1\% weight/volume) reduced the loss in viability between days 5 and 10 (Fig. 1, Table 1). Addition of albumin to FCS-medium had no influence on the percentage of neutral red positive cells (Table 1 ) but exerted a protective effect in media without serum (Fig. 1). The presence of IBMX $(50 \mu \mathrm{mol} / \mathrm{l})$ improved cell survival in all conditions with $1 \%$ BSA (Table 1), leading to $50 \%$ live cells without serum or ultroser and $75 \%$ or more in those with serum or ultroser; lower IBMX concentrations $(25 \mu \mathrm{mol} / \mathrm{l})$ were less protective (data not shown).
All subsequent testing was conducted in Ham's F10 containing $1 \% \mathrm{BSA}$ and $50 \mu \mathrm{mol} / \mathrm{l} \mathrm{IBMX} \mathrm{(=} \mathrm{basal}$ medium).

\section{Effect of glucose}

The percent viable cells on day 10 varied markedly with the glucose concentration in the culture medium. At $2.8 \mathrm{mmol} / 1$, only $15 \%$ of the cells remained neutral red positive (Fig. 2). Between 2.8 and $10 \mathrm{mmol} / \mathrm{l}$, glucose increased the percentage of live cells dose-dependently (Fig. 2). Similar conclusions were reached with trypan blue as indicator of the percent dead cells (data not shown). In parallel cultures of islet endocrine non-beta cells, the percent viable cells was not influenced by the medium glucose concentration (Fig. 2). The protective effect of glucose on the survival of cultured beta cells could not be repeated with galactose, fructose or sorbitol. In glucose-free medium containing $10 \mathrm{mmol} / \mathrm{l}$ of these sugars, less than $20 \%$ of the beta cells survived a 9-day culture period (data not shown). Addition of $4 \mathrm{mmol} / \mathrm{l} \mathrm{D}$-glucose to basal medium containing $6 \mathrm{mmol} / \mathrm{l}$ glucose not only resulted in an increased percent viable cells but also in a two-fold higher recovery of cellular insulin on day 10 (Table 2). Addition of $4 \mathrm{mmol} / \mathrm{l} \mathrm{L}$-glucose decreased the percent viable cells; $4 \mathrm{mmol} / \mathrm{l}$ supplements of sorbitol and galactose exerted a minor beneficial effect on cell viability; $4 \mathrm{mmol} / \mathrm{l}$ fructose increased the percent neutral red positive cells and the insulin content (Table 2).

When the medium with $10 \mathrm{mmol} / 1$ glucose was further supplemented with D-glucose, a dose-dependent decrease in the percent neutral red positive cells occurred (Fig. 2); the presence of more dead cells at 20 and $40 \mathrm{mmol} / \mathrm{l}$ glucose was confirmed by trypan blue staining (data not shown). Supplementation of the $10 \mathrm{mmol} / \mathrm{l} \mathrm{D}$-glucose medium with $10 \mathrm{mmol} / \mathrm{l} \mathrm{L}$-glucose, D-galactose or D-sorbitol was without effect (data not shown). With $10 \mathrm{mmol} / \mathrm{l}$ fructose added, a minor decrease in viability was noticed ( $69 \%$ viable cells vs $80 \%$ in $10 \mathrm{mmol} / \mathrm{l}$ glucose control, $p<0.05)$. 
Table 2. Effect of nutrient supplements on the survival and cellular insulin mass of islet beta cells after 9 days of culture

\begin{tabular}{lllll}
\hline $\begin{array}{l}\text { Addition to } \\
\text { basal medium }\end{array}$ & & $\begin{array}{l}\text { Survival } \\
\text { (\% NR + Cells) }\end{array}$ & $\begin{array}{l}\text { Cellular insulin mass } \\
\text { (ng insulin / 10 cells at start) }\end{array}$ \\
\hline None & & $(14)$ & $51 \pm 1$ & $10.4 \pm 0.8$ \\
D-Glucose & $4 \mathrm{mmol} / \mathrm{l}$ & $(14)$ & $80 \pm 7^{\mathrm{c}}$ & $21.6 \pm 1.9^{\mathrm{c}}$ \\
L-Glucose & $4 \mathrm{mmol} / \mathrm{l}$ & $(4)$ & $41 \pm 1^{\mathrm{b}}$ & $13.5 \pm 2.5$ \\
D-Sorbitol & $4 \mathrm{mmol} / 1$ & $(4)$ & $59 \pm 5^{\mathrm{a}}$ & $13.0 \pm 0.8^{\mathrm{a}}$ \\
D-Galactose & $4 \mathrm{mmol} / 1$ & $(6)$ & $61 \pm 1^{\mathrm{b}}$ & $13.7 \pm 1.3$ \\
D-Fructose & $4 \mathrm{mmol} / 1$ & $(4)$ & $70 \pm 5^{\mathrm{c}}$ & $20.2 \pm 4.0^{\mathrm{a}}$ \\
L-Leucine & $2 \mathrm{mmol} / 1$ & $(6)$ & $81 \pm 2^{\mathrm{c}}$ & $18.9 \pm 2.1^{\mathrm{c}}$ \\
L-Glutamine & $2 \mathrm{mmol} / 1$ & $(9)$ & $62 \pm 1^{\mathrm{a}}$ & $13.0 \pm 1.2$ \\
L-Leucine + L-Glutamine & $2 \mathrm{mmol} / \mathrm{l}$ each & $(6)$ & $80 \pm 2^{\mathrm{c}}$ & $22.7 \pm 1.8^{\mathrm{c}}$ \\
\hline
\end{tabular}

Data represent mean \pm SEM of $(n)$ independent experiments. NR + , Neutral red positive. ${ }^{\mathrm{a}} p<0.05,{ }^{\mathrm{b}} p<0.01,{ }^{\mathrm{c}} p<0.001$ vs basal medium [Ham's F10 with $1 \%$ BSA, $50 \mu \mathrm{mol} / 1$ IBMX and $6 \mathrm{mmol} / \mathrm{l}$ glucose $=$ none] (unpaired Student's $t$-test)

Table 3. Effect of growth promoting peptides on survival and cellular insulin mass of islet beta cells after 9 days of culture

\begin{tabular}{lrrll}
$\begin{array}{l}\text { Addition to } \\
\text { basal medium }\end{array}$ & & & $\begin{array}{l}\text { Survival } \\
\text { (\% Surviving cells) }\end{array}$ & $\begin{array}{l}\text { Cellular insulin mass } \\
\text { (ng insulin } / 10^{3} \text { cells at start) }\end{array}$ \\
\hline None & & $(34)$ & $52 \pm 1$ & $11.5 \pm 0.6$ \\
IGF-I & $2 \mathrm{ng} / \mathrm{ml}$ & $(6)$ & $61 \pm 3^{\mathrm{a}}$ & $16.4 \pm 1.9^{\mathrm{a}}$ \\
& $10 \mathrm{ng} / \mathrm{ml}$ & $(6)$ & $62 \pm 1^{\mathrm{b}}$ & $16.2 \pm 1.3^{\mathrm{c}}$ \\
& $50 \mathrm{ng} / \mathrm{ml}$ & $(9)$ & $60 \pm 3^{\mathrm{a}}$ & $16.6 \pm 1.0^{\mathrm{c}}$ \\
IGF-II & $50 \mathrm{ng} / \mathrm{ml}$ & $(5)$ & $65 \pm 3^{\mathrm{a}}$ & $12.8 \pm 1.2$ \\
EGF & $50 \mathrm{ng} / \mathrm{ml}$ & $(7)$ & $60 \pm 3^{\mathrm{a}}$ & $12.0 \pm 0.7$ \\
& $250 \mathrm{ng} / \mathrm{ml}$ & $(4)$ & $66 \pm 3^{\mathrm{a}}$ & $12.4 \pm 0.5$ \\
GH & $0.1 \mu \mathrm{g} / \mathrm{ml}$ & $(7)$ & $64 \pm 2^{\mathrm{b}}$ & $13.8 \pm 1.4$ \\
& $1 \mu \mathrm{g} / \mathrm{ml}$ & $(16)$ & $71 \pm 1^{\mathrm{c}}$ & $21.2 \pm 1.4^{\mathrm{c}}$ \\
IGF-I + & $50 \mathrm{ng} / \mathrm{ml}+$ & & $76 \pm 2^{\mathrm{c}}$ & $30.3 \pm 3.5^{\mathrm{c}}$ \\
GH & $1 \mu \mathrm{g} / \mathrm{ml}$ & $(6)$ & $78 \pm 1^{\mathrm{c}}$ & $30.1 \pm 2.5^{\mathrm{c}}$ \\
FCS & $5 \%$ & $(12)$ &
\end{tabular}

Data represent mean \pm SEM of $(n)$ experiments. IGF, Insulin-like growth factor; EGF, epidermal growth factor; GH, growth hormone; FCS, fetal calf serum. ${ }^{\text {a }} p<0.05,{ }^{\mathrm{b}} p<0.01,{ }^{\circ} p<0.001$ vs basal medium (unpaired Student's $t$-test)

\section{Effects of leucine and glutamine}

In glucose-free medium containing 5 or $10 \mathrm{mmol} / \mathrm{l}$ leucine, $60-70 \%$ of the beta cells were neutral red positive on day 10 ; with $2 \mathrm{mmol} / \mathrm{l}$ leucine, only $29 \%$ of the cells remained viable $(p<0.01$ vs 5 or $10 \mathrm{mmol} / \mathrm{l})$. When leucine was added to the $6 \mathrm{mmol} / \mathrm{l}$ glucose medium, its maximal protective effect was observed at $2 \mathrm{mmol} / \mathrm{l}$, as reflected in a higher percentage of viable cells and a higher cellular insulin mass (Table 2).

Addition of $2 \mathrm{mmol} / \mathrm{l}$ glutamine to the $6 \mathrm{mmol} / \mathrm{l} \mathrm{glu}-$ cose medium was also beneficial, but to a lesser extent than L-leucine or D-glucose (Table 2). Higher glutamine levels $(5 \mathrm{mmol} / \mathrm{l})$ did not result in more pronounced effects.

\section{Effect of growth promoting peptides}

Addition of IGF-I to the basal medium promoted cell survival over the 9-day culture period (Table 3 ); the effect was noticed at $2 \mathrm{ng} / \mathrm{ml}$ (Table 3 ). A comparable effect was obtained with 25 -fold higher concentrations of IGF-II or EGF (Table 3) but not with fibroblast growth factor (data not shown). The presence of growth hormone (100-1000 $\mathrm{ng} / \mathrm{ml})$ led to higher numbers of viable cells than in basal medium with or without IGF-I (Table 3). Lower concentrations of IGF-II, EGF or growth hormone had no effect (data not shown). Similar effects of IGF-I, IGF-II and growth hormone were measured in islet endocrine non-beta cells (data not shown).

Growth hormone and IGF-I also increased the recovery of cellular insulin on day 10 (Table 3 ). Their effects were additive, resulting in similar cellular insulin 
Table 4. Effects of pancreatic hormones on survival and cellular insulin mass of islet beta cells after 9 days of culture

\begin{tabular}{|c|c|c|c|c|}
\hline $\begin{array}{l}\text { Addition to } \\
\text { basal medium }\end{array}$ & & & $\begin{array}{l}\text { Survival } \\
(\% \mathrm{NR}+\text { cells })\end{array}$ & $\begin{array}{l}\text { Cellular insulin mass } \\
\text { (ng insulin } / 10^{3} \text { cells at start) }\end{array}$ \\
\hline None & & $(12)$ & $55 \pm 2$ & $11.6 \pm 1.1$ \\
\hline Glucagon & $10^{-8} \mathrm{~mol} / \mathrm{l}$ & $(8)$ & $72 \pm 1^{b}$ & $15.1 \pm 1.2^{\mathrm{a}}$ \\
\hline Insulin & $10^{-6} \mathrm{~mol} / \mathrm{l}$ & (4) & $48 \pm 4$ & ND \\
\hline
\end{tabular}

Data represent mean \pm SEM of $(n)$ experiments. $\mathrm{NR}+$, Neutral red positive; ND, not determined. ${ }^{\mathrm{a}} p<0.01$, ${ }^{\mathrm{b}} p<0.001 \mathrm{vs}$ basal medium (none) (unpaired Student's $t$-test)

Table 5. Insulin release from single beta cells during culture

\begin{tabular}{|c|c|c|c|c|c|c|c|}
\hline \multirow{2}{*}{$\begin{array}{l}\text { Basal medium } \\
\text { Addition }\end{array}$} & & \multicolumn{2}{|c|}{ Cellular insulin concent } & \multicolumn{3}{|c|}{ Medium insulin content } & \multirow{2}{*}{$\begin{array}{l}\text { Total insulin } \\
\text { recovery }^{\mathrm{a}}\end{array}$} \\
\hline & & $(n)$ & Day 10 & $\begin{array}{l}\text { Day } 5 \\
(24 \mathrm{~h}) \\
\end{array}$ & $\begin{array}{l}\text { Day } 9 \\
(24 \mathrm{~h})\end{array}$ & $\begin{array}{l}\text { Total } \\
\text { (9 days) }\end{array}$ & \\
\hline None & & (11) & $11.8 \pm 1.1$ & $4.3 \pm 0.4$ & $0.7 \pm 0.3$ & $32.5 \pm 2.3$ & $44.3 \pm 2.9$ \\
\hline Glucose & $4 \mathrm{mmol} / 1$ & (6) & $26.6 \pm 2.4^{d}$ & $12.5 \pm 1.8^{\mathrm{d}}$ & $11.1 \pm 1.0^{d}$ & $114.1 \pm 7.5^{\mathrm{d}}$ & $140.7 \pm 7.9^{d}$ \\
\hline Growth hormone & $1 \mu \mathrm{g} / \mathrm{ml}$ & (8) & $20.7 \pm 1.7^{\mathrm{d}}$ & $7.1 \pm 0.8^{c}$ & $0.5 \pm 0.3$ & $43.3 \pm 3.0^{c}$ & $64.0 \pm 4.5^{\mathrm{d}}$ \\
\hline Glucagon & $10^{-8} \mathrm{~mol} / 1$ & (3) & $15.5 \pm 1.8^{\mathrm{b}}$ & $5.9 \pm 1.3$ & $0.6 \pm 0.1$ & $57.2 \pm 2.8^{\mathrm{d}}$ & $74.5 \pm 4.5^{\mathrm{a}}$ \\
\hline Fetal calf serum & $5 \%$ & (6) & $29.4 \pm 2.5^{\mathrm{d}}$ & $3.1 \pm 0.5^{\mathrm{b}}$ & $0.8 \pm 0.3$ & $30.4 \pm 4.1$ & $59.8 \pm 5.8^{b}$ \\
\hline
\end{tabular}

a Total insulin recovery is the sum of cellular insulin content on day 10 plus total medium insulin over 9 days culture. Data represent mean \pm SEM of $(n)$ independent experiments. ${ }^{\mathrm{b}} p<0.05,{ }^{\mathrm{c}} p<0.01,{ }^{\mathrm{d}} p<0.001$ vs basal medium (none) (unpaired Student's $t$-test)

contents measured in the presence of $5 \%$ FCS, i.e., three times the values measured in basal medium (Table 3).

\section{Effect of pancreatic hormones}

In preliminary studies, medium collected from cultured islet endocrine non-beta cells was found to promote the survival of purified beta cells in culture (data not shown). Addition of $10^{-8} \mathrm{~mol} / \mathrm{l}$ glucagon to basal medium significantly increased the percent neutral red positive cells and the cellular insulin mass on day 10 (Table 4). After culture with somatostatin $\left(10^{-8} \mathrm{~mol} / \mathrm{l}\right)$, less viable cells were present but the insulin content was not statistically decreased (Table 4). Supplements of porcine insulin to the basal medium $\left(10^{-8}\right.$ to $\left.10^{-6} \mathrm{~mol} / \mathrm{l}\right)$ had no detectable effect on the survival of cultured beta cells (data not shown). No glucagon or somatostatin was detected in the culture medium of purified beta-cell preparations.

\section{Effect of supplements previously used in serum-free media}

Serum-free culture conditions have been described for other cell types [4]. We have tested the effects of the following media supplements used in previous studies: glutamine, insulin, transferrin, $\mathrm{T}_{3}$, hydrocortisone, selenite, EGF, glucagon and BSA. Of this series, only glutamine $(2 \mathrm{mmol} / \mathrm{l})$, hydrocortisone $\left(10^{-6} \mathrm{~mol} / \mathrm{l}\right)$, EGF (50 ng/ml), glucagon $\left(10^{-8} \mathrm{~mol} / \mathrm{l}\right)$ and BSA $(1 \%)$ were found to prolong survival of single beta cells in culture; the other agents had no effect.

\section{Insulin discharge in the culture medium}

Conditions with increased beta-cell survival (i.e., $>70 \%$ ) differed in the amount of insulin that was discharged in the medium. Cells incubated under nutrient supplementation (addition of $4 \mathrm{mmol} / 1$ glucose or $2 \mathrm{mmol} / 1$ leucine) discharged 2-4 times more hormone over the 9-day culture period than those in basal medium alone (Table 5). A higher discharge rate was noticed throughout the entire culture period but became more pronounced (8- to 15 -fold higher) between days 5 and 9 of culture, when the rate from the control cells had declined by more than $80 \%$ (Table 5). Total insulin recovery (i.e. cellular insulin on day 10 plus total medium insulin over 9 days) was also two- to four-fold higher in the conditions with nutrient supplements than in basal medium. Since the number of surviving beta cells was only $60 \%$ higher, it is clear that these conditions should be accompanied by a higher rate of hormone synthesis (Table 5). Culture with growth hormone, glucagon or serum also led to a higher insulin recovery than in the basal control condition, but this 
reflected essentially the survival of more beta cells (Table 5). The condition with $5 \%$ FCS was characterized by the lowest fractional discharge of insulin: the total amount of insulin in the medium was similar to the cellular insulin content on day 10 , whereas this fraction was two- to five-fold higher in all other conditions (Table 5). Therefore, it seems likely that addition of serum suppresses hormone release from the surviving cells.

\section{Discussion}

Few studies have searched for culture conditions that are optimal for adult pancreatic beta cells. On the basis of the glucose responsiveness of mouse islets cultured in suspension, Andersson [1] concluded that RPMI1640 medium containing serum and $11 \mathrm{mmol} / \mathrm{l}$ glucose was superior to other media or to conditions without serum or with lower glucose concentrations. Clark and Chick [2] developed a serum-free RPMI mixture that was equally successful as a serum-containing medium in preserving glucose-induced insulin release from rat islet cells in monolayer. Their medium supplements included human serum albumin, ethanolamine and phosphoethanolamine, transferrin, $\mathrm{T}_{3}$, IGF-I and prolactin [2].The extent to which these media preserve the initial number of viable beta cells is not yet known. The amplitude of secretory or biosynthetic responses to high glucose levels represents an index for the regulatory effect of glucose on the remaining beta cells rather than an expression of the degree of beta-cell survival during culture. In the present study we have quantified the survival of adult rat islet beta cells in different culture conditions.

Selection of Ham's F10-medium was based on the following arguments: this enriched medium is, among others, more appropriate for developing serum-free culture conditions [8]; its low calcium content $(0.3 \mathrm{mmol} / \mathrm{l})$ may help prevent depletion of the cellular hormone store as it suppresses insulin release but not insulin synthesis [9]; its glucose level $(6 \mathrm{mmol} / \mathrm{l})$ is lower than that in RPMI-1640 (11 mmol/l) which facilitates comparisons between normal and high glucose levels; its lower methionine and tyrosine levels are advantageous for tracer studies. Preliminary studies with $10 \%$ FCS had indicated that more than $90 \%$ of the beta cells survived a 24-h culture in Ham's F10.

After 9 days of culture in Ham's F10 without supplements, less than $10 \%$ of the initial beta cells remained viable. The presence of calf serum dose-dependently increased cell survival to $54 \%$. This protective effect of serum is partly attributed to low molecular weight agents, which can be absorbed by charcoal and substituted by ultroser, and partly to larger proteins which can be replaced by charcoal-treated albumin.

The need for nutrient supplementation to the basal medium containing $6 \mathrm{mmol} / \mathrm{l}$ glucose was indicated by the cytoprotective effect of glucose. This effect was beta-cell specific as it was not observed with cultured islet endocrine non-beta cells. It was dose-dependent between 2.8 and $10 \mathrm{mmol} / 1$ glucose, the range over which the sugar recruits beta cells into metabolic and functional activities [10-13]. Non-metabolizable monosaccharides failed to promote beta-cell survival. Leucine, a metabolizable nutrient, has previously been found to replace glucose for maintaining functions in cultured beta cells [14]. Its addition to the basal medium with intermediate glucose level increased cell survival. The need for nutrient supplements to medium with $6 \mathrm{mmol} / \mathrm{l}$ glucose can be attributed to the higher metabolic threshold of a fraction of islet beta cells: more than $30 \%$ of the cells require glucose levels above $6 \mathrm{mmol} / \mathrm{l}$ to become metabolically and biosynthetically active in vitro $[8,11]$. As glucose metabolism produces reducing equivalents which protect against oxidative damage [7], it is conceivable that beta cells with a higher threshold are more sensitive to oxidative events at intermediate glucose levels.

Survival of islet beta cells was lower after culture at 20 or $40 \mathrm{mmol} / 1$ glucose than after $10 \mathrm{mmol} / \mathrm{l}$. We have not yet determined whether the damaged beta cells belong to glucose-sensitive or insensitive subpopulations. The mechanism behind this apparent glucotoxicity is unclear. Since addition of $10 \mathrm{mmol} / \mathrm{l}$ non-metabolizable monosaccharides to Ham's F10 with $10 \mathrm{mmol} / \mathrm{l}$ glucose did not reduce beta-cell survival, the higher extracellular osmolarity of the $20 \mathrm{mmol} / \mathrm{l}$ glucose medium is not a likely explanation for the described cytotoxicity. It remains to be examined whether an intracellular accumulation of metabolites in excess of catabolic fluxes can initiate cellular dysregulation or deterioration or both.

Several growth promoting peptides improved betacell survival. The effect of growth hormone was additive to that of IGF-I, suggesting that the two peptides protect beta cells independently, possibly through the growth hormone/prolactin and IGF-I receptors of islet beta cells [15-18]. Cell survival was not influenced by insulin, $T_{3}$ or transferrin, but was improved by addition of glucagon and reduced by somatostatin, two hormones that regulate cellular cyclic AMP levels [19].

As expected, conditions with higher numbers of surviving beta cells contained a higher cellular insulin mass at the end of culture. When this hormone content was reflected against the number of surviving cells and against the total amount of insulin that was discharged in the medium, three types of medium supplements were distinguished. First, those where the increase in surviving beta cells is accompanied by a proportional rise in insulin discharge - and thus conceivably release - for example after addition of substances which are known to elevate cellular cyclic AMP levels. Secondly, conditions where the larger cellular insulin mass not only resulted from an increased number of surviving 
cells but also from a reduced hormone discharge in the medium, such as in the presence of serum. Thirdly, substances which maintained higher insulin reserves through greater beta-cell survival and higher rates of hormone synthesis. Although we did not measure protein synthesis directly, conditions with larger amounts of recovered insulin for equal cell survival $(>70 \%$ ) can be considered as maintaining higher rates of hormone synthesis. This was the case after nutrient supplementation, such as at $10 \mathrm{mmol} / 1$ glucose or $6 \mathrm{mmol} / 1$ glucose plus $2 \mathrm{mmol} / \mathrm{l}$ leucine.

Four groups of substances have been identified for composing a serum-free medium in which survival of plated single beta cells is better than in basal Ham's F10 medium supplemented with only FCS: albumin, agents that elevate cellular cyclic AMP levels such as glucagon and IBMX, growth factors such as IGF-I plus growth hormone, metabolized nutrients at concentrations that activate a maximal number of cells. Such medium is useful for studies which investigate cytotoxic and cytoprotective conditions for the beta cells. Further experiments should assess whether these serum-free culture conditions also improve survival and function of betacell aggregates in suspension. It may indeed be necessary - both for transplantation purposes and for functional experiments - to culture beta-cell preparations in serum-free conditions. The question is raised whether additional supplements are also needed for preserving beta-cell survival in islets and beta-cell aggregates that are cultured in serum.

Acknowledgements. The authors thank their collaborators at the department for their help in the preparation of islet beta cells. They are grateful to Mr. G. Schoonjans for performing the immunoassays and to Ms. N. Van Slycke for secretarial support. Part of this work was presented at the 25 th Annual Meeting of the European Association for the Study of Diabetes, Lisbon, Portugal, 1989. This work was supported by grants from the Vlaamse Gemeenschap (92/97-1807) and from the Belgian Fonds voor Geneeskundig Wetenschappelijk Onderzoek $(3.0075 .88,3.0132 .91)$.

\section{References}

1. Andersson A (1978) Isolated mouse pancreatic islets in culture: effects of serum and different culture media on the insulin production of the islets. Diabetologia 14:397-404

2. Clark SA, Chick WL (1990) Islet cell culture in defined serum-free medium. Endocrinology 126: 1895-1903

3. Buitrago A, Gylfe E, Hellman B, Idahl L-Å, Johansson M (1975) Function of microdissected pancreatic islets cultured in a chemically defined medium. I. Insulin content and release. Diabetologia 11: 535-540
4. Gylfe E (1977) Specific glucose protection of pancreatic $\beta$ cell function during culture in chemically defined medium. Endocrinology 101: 1281-1285

5. Nielsen JH (1985) Growth and function of the pancreatic $\beta$ cells in vitro: effects of glucose, hormones and serum factors on mouse, rat and human pancreatic islets in organ culture. Acta Endocrinol (Copenh), 266 [Suppl]: 1-39

6. Pipeleers DG, In'T Veld PA, Van De Winkel M, Maes E, Schuit FC, Gepts W (1985) A new in vitro model for the study of pancreatic A and B cells. Endocrinology 117: 806-816

7. Pipeleers DG, Van De Winkel M (1986) Pancreatic B cells possess defense mechanisms against cell-specific toxicity. Proc Natl Acad Sci USA 83: 5267-5271

8. Freshney RI (1987) The culture environment: substrate, gas phase, medium, and temperature. In: Freshney RI (ed) Culture of animal cells. Alan R. Liss, Inc., New York, pp 57-84

9. Pipeleers DG, Marichal M, Malaisse WJ (1973) The stimulus-secretion coupling of glucose-induced insulin release. XV. Participation of cations in the recognition of glucose by the B cell. Endocrinology 93: 1012-1018

10. Pipeleers DG (1992) Heterogeneity in pancreatic B-cell population. Diabetes 41: 777-781

11. Schuit FC, In't Veld PA, Pipeleers DG (1988) Glucose stimulated proinsulin biosynthesis by a dose-dependent recruitment of pancreatic beta cells. Proc Natl Acad Sci USA 85: $3865-3869$

12. Hiriart M, Ramires-Medeles MC (1991) Functional subpopulations of individual pancreatic B cells in culture. Endocrinology 128: 3193-3198

13. Bosco D, Meda P (1991) Actively synthesizing B-cells secrete preferentially after glucose stimulation. Endocrinology 129: $3157-3166$

14. Andersson A, Hoiriis-Nielsen J, Borg LAH (1977) Effects of L-leucine on the insulin production, oxidative metabolism and mitochondrial ultrastructure of isolated mouse pancreatic islets in tissue culture. Diabetologia 13: 59-69

15. Van Schravendijk CFH, Foriers A, Van den Brande JL, Pipeleers DG (1987) Evidence for the presence of type I insulinlike growth factor receptors on rat pancreatic A and B cells. Endocrinology 121: 1784-1788

16. Billestrup N, Martin JM (1985) Growth hormone binding to specific receptors stimulates growth and function of cloned insulin-producing rat insulinoma RIN-5 AH cells. Endocrinology 116: 1175-1181

17. Møldrup A, Billestrup N, Thorn NA, Lernmark A, Nielsen $\mathrm{JH}(1989)$ Multiple growth hormone-binding proteins are expressed on insulin-producing cells. Mol Endocrinology 3: 1173-1182

18. Brelje TC, Scharp DW, Lacy PE et al. (1993) Effect of homologous placental lactogens, prolactins, and growth hormones on islet secretion in rat, mouse, and human islets: implication for placental lactogen regulation of islet function during pregnancy. Endocrinology 132: 879-897

19. Schuit FC, Pipeleers DG (1985) Regulation of adenosine $3^{\prime}$, $5^{\prime}$-monophosphate levels in the pancreatic B cells. Endocrinology 117: 834-840 